\title{
更新・廃止計画のための 多時点最適施設配置モデル
}

\author{
大窪 和明 1 ・奥村 誠 2 - 吾妻 樹3 \\ 1正会員 埼玉大学大学院助教 理工学研究科（†338-8570 さいたま市桜区下大久保255) \\ E-mail: okubo@dp.civil.saitama-u.ac.jp \\ 2正会員 東北大学教授 災害科学国際研究所（干980-0845 仙台市青葉区荒巻字青葉468-1） \\ E-mail:mokmr@m.tohoku.ac.jp \\ 3 正会員 KDDI株式会社（一102-0072 東京都千代田区飯田橋3-10-10） \\ E-mail: agatsuma.dk@gmail.com
}

\begin{abstract}
多くの公共施設が而用年数を迎えようとしている中，国民が受けるサービス水準が低下することのない ように，長期的な視点から施設の更新・廃止計画を考えていく必要がある．特に，同じような機能を持つ 複数の施設が空間的に散在している場合に，どの施設を維持・更新し，どの施設を廃止するべきかを判断 するための科学的手法が求められている。本論文では，老朽化を考慮した施設の更新・廃止計画を検討す るために，施設の供用年数を内生化した整数計画問題として多時点最適施設配置モデルを提案する.さら に，提案モデルを仮想的な廃棄物処理施設群に適用し，施設の地理的条件などの要因が施設の更新・廃止 計画にもたらす影響を明らかにする.
\end{abstract}

Key Words : asset management, facility location problem, mixed integer programming

\section{1. 本研究の背景と先行研究}

\section{(1) 公共施設の更新・廃止を取り巻く現状}

わが国の公共施設は高度成長期に大量に整備され，そ の多くが耐用年数を迎えようとしている. 現在，人口減 少の時代を迎え，施設の老朽化や自治体の財政状況の悪 化が進む中で，多くの自治体が施設の再編を迫られてい る. 例えば，2014年1月に総務省は地方自治体に対して 公共施設等総合管理計画の策定を要請した. この計画に おいて各地方自治体は，中長期的な施設の維持管理・更 新の費用を考慮した上で，学校教育施設や図書館など所 有している公共施設の統廃合や長寿命化，維持管理・補 修・大規模改修・更新の方針を示すことが求められてい る1).また，さいたま市においては，第三次さいたま市 一般廃央物処理基本計画において，ごみ処理施設を現在 (2014年)の5箇所から，2021年度には3箇所の施設に集約 し，より効率的な処理体制の実現を目指すなど，人口の 減少をふまえた上での効率的な施設再編計画への社会的 なニーズが高まっている2).

学校教育施設, 図書館やごみ処理施設といった公共施 設は, 一つの施設を廃止したとしても, 別の場所に同じ 機能を持つ施設が存在すれば，サービスを代替的に提供
できる点に特徵がある. そのため, 施設の統廃合や機能 の集約を進めていく上で，現在その施設が受け持ってい る機能を提供することができる代替的な施設の存在を考 慮に入れる必要がある. 特に, 学校教育施設や図書館な ど，サービスを受けるための移動費用が無視できない場 合や，ごみ処理施設のように，ごみ処理の総費用に占め る収集・運搬費用の割合が高い場合は，施設の老朽化度 合いだけでなく, 近隣の代替的な施設との地理的な条件 を考慮した適切な更新・廃止計画の検討が望まれる.

\section{(2) アセットマネジメントに関する先行研究}

土木工学の分野においては早くから, 社会インフラの 減耗や老朽化を考慮した最適補修戦略に関する研究が数 多く存在する. 例えば，栗野ら33や小林ら4においては， 単独の土木施設に着目してライフサイクルコスト(Life Cycle Cost: LCC)を最小にするための最適な更新タイミン グや更新後の機能水準を求める方法論を提案している.

これに対し小澤ら5や江橋らのはアッットネジメント に関する現在の調査や研究は維持管理あるいはメンテナ ンスの延長もしくは改善に止まっている場合が多いと主 張する，小澤らは，社会資本のアセットマネジメントを， 運用・管理の費用を抑えつつ，質の高いサービスを提供 
することによって社会資本の資産価值を最大化する活動 として位置づけている，そのために必要な意思決定には， i)個別資産の計画 : 点検, 評価によって得られた結果に 基づき，個々の施設の維持管理計画を策定すること，ii) 資産群全体の意志決定 : 限られた予算を効果的に配分す るため, 施設群に含まれる複数の施設に対して優先順位 をつけた上で，投資（事業実施）の意志決定を行うこと を挙げている.これまでの多くの研究は単独施設を対象 としたLCC最小化というi)の段階に止まっており，施設 群を対象とするii)の観点が久如していると指摘している.

織田澤らクや堀ら8)などは, 道路付帯施設や下水道施設 が, 定期的な点検や補修が必要な複数の要素から構成さ れている点に着目し，補修を同期化することの効果を分 析している. これらの研究では, 複数の要素を要素群と して見ることによって, 小澤らのii)の観点を満たしてい ると言えるが，要素間の関係性が技術的に規定されてい る状況を扱っている. これに対して本研究では, 同地域 内に同じ機能を提供寸る施設群について，各施設間に代 替性があるが，その関係性を利用するために追加的な費 用がかかる場合の最適な更新・廃止計画を検討寸る.

\section{(3) 本研究の目的}

本研究では同じ機能を有寸る複数の施設からなる施設 群を対象として, 全施設のLCC最小化が達成できるよう に施設の更新と不要な施設の廃止を計画できるモデルを 提案する. 施設の廃止の意志決定には，廃止する施設が 賄っていた需要を他の施設に移すための追加的な移動・ 輸送費用および，施設の容量が問題となるため，容量制 約付の最適施設配置モデル99, 10)を基本として最適化モデ ルを構築することが実際的である. また施設の老朽化の 進行を維持管理費用の増加として明示的に考慮する。 そ の上で，施設の重要度によっては，より長く使用するべ き施設を明らかにするため, 供用年数を内生変数として 考慮できるように定式化する.

次章では, これらの要求を満たすような多時点最適施 設配置モデルを混合整数計画問題として定式化する. 第 3章では，このモデルを仮想的な公共施設群に適用して， モデルの基本的な特性を確認し，施設の地理的条件が更 新・廃止計画にもたらす影響を明らかにする。第4章で は, 公共サービスに対する需要の将来予測や維持管理費 用が，更新・廃止計画にもたらす影響を明らかにする.

\section{2. 多時点最適施設配置モデル}

\section{(1) 問題設定と定式化の方針}

以下では，モデルに関する具体的なイメージを持って もらうために，ごみ処理施設を対象として説明する。す
なわち廃棄物を発生地点から, ごみ処理施設に輸送し, 焼却処理するまでを考えたときの，施設の更新・廃止計 画を多時点最適施設配置モデルとして定式化する．ただ し，公共施設の利用者が居住地から施設まで移動して, 公共サービスを受けるといらタイプの公共施設にも同様 に適用可能なモデルとなっている.

本研究では, 離散的な多時点(多期間)のそれぞれにお いて複数の発生点から廃棄物が発生し, その廃棄物を廃 棄物処理施設まで輸送して, 各施設の処理能力内で焼却 処理する状況を考える. 各時点において, 各施設をその まま使用するか，更新するか，もしくは廃止するかを決 定する. 簡単のため, ある期の期首に更新を決定し施設 更新費用を投資寸れば，その期から所定の処理能力が利 用できるものと仮定する. 各期に発生する廃棄物はす心゙ て当期に処理するものとする.

今回は, 既存の施設と用地をできるだけ将来に有效活 用寸るという観点から，新たな用地での新規建設を考え ない.しかし，施設の更新・廃止に関する変数の選択肢 集合に新たな用地取得による施設の新規建設という選択 肢を含め，それに伴う費用を考えることにより，本モデ ルの枠組み内で, 新たな用地での新規建設を取り扱うこ とは可能である.

今後の人口減少により, 廃棄物の発生量が減少してい くことを考え，施設を更新するときの選択肢として，施 設の規模（処理可能量）を現在のままとするか, 半分の 規模とするかを選択させる. このとき，小規模の施設と して更新すれば，施設の更新費用と，その後の施設の維 持管理費用を小さく抑えることができると仮定する.

\section{（2）定式化の準備}

まずインデックスを示す．時間（期） $t$ は整数で設定 し，計画期間を $[0, T]$ とする. ここでは自治体の長期的コ ス卜を勘案して長期的な更新・廃止計画を検討するとい う立場から年度のレベルで考えれば十分であると判断し， 時間（期）を整数で扱う。廃棄物の発生地点を $k$, 廃棄 物処理施設の地点を $j$, 施設の規模を $i て ゙$ 表す.

次に外生的に与える定数を示す. 発生地点 $k$ 小ら施設 立地点ままでの単位廃裹物量あたりの輸送費用を $c_{k j}$, 規 模がiの施設において廃棄物を処理したときの単位廃棄 物量あたりの処理費用を $w^{i}$ とする. また地点 $j$ の規模 $i の$ 施設における処理可能量を $M_{j}^{i}, \quad t$ 期における地点 $k$ での 廃棄物発生量を $G_{k, t}$ とする. 施設の維持管理費用は供用 年数に比例して発生寸ると仮定し，その係数を $r_{j}^{i}$ とする. 地点 $j$ 施設を規模iの施設に更新するための更新費用を $f_{j}^{i}$ とする. さらに割引率を $\gamma$ とする.

モデルの操作変数は, $t$ 期における廃棄物の発生地点 $k$ から施設立地点 $j に$ 立地する規模 $门$ 施設への廃棄物輸送 量の $x_{k j, t}^{i}$ のみが連続変数である. これらに加えて, $t$ 期 
に施設 $j$ を規模 $i$ 施設に更新することを表す $[0-1]$ 変数の $z_{j, t}^{i}$ と，施設の廃止を表す $[0-1]$ 変数の $v_{j, t}^{i}$ を考える.また，

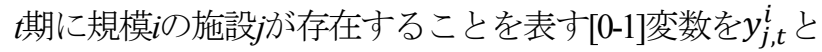
し，当該地域に施設が存在寸る場合を $y_{j, t}^{i}=1$, 存在しな い場合を $y_{j, t}^{i}=0$ で表現する. さらに， $t$ 期における規模 $i$ の施設 $j$ の供用年数を表寸非負の整数変数 $q_{j, t}^{i}$ を考える. $y_{j, t}^{i}$ と $q_{j, t}^{i}$ は定式化上は操作変数として扱うが，実際は制 約条件を通して值が決まる内生変数である.

\section{（3）施設の更新・廃止の表現と供用年数の内生化}

施設の更新・廃止と施設の存在との関係は, 前節の操 作変数を用いて, 次のように表すことができる.

$$
y_{j, t}^{i}=y_{j, t-1}^{i}+z_{j, t}^{i}-v_{j, t}^{i} \quad \forall i \in I, \forall j \in J, \forall t \in T
$$

式(1)において， $(t-1)$ 期に既存施設が存在する状況 $\left(y_{j, t-1}^{i}=1\right)$ で $t$ 期にも施設が存在する $\left(y_{j, t}^{i}=1\right)$ ための 条件は， a) $t$ 期に施設の廃止も更新もしない場合 $\left.\left(z_{j, t}^{i}=v_{j, t}^{i}=0\right), \quad b\right) t$ 期に施設を廃止し，同じ地点に施 設を更新する場合 $\left(z_{j, t}^{i}=v_{j, t}^{i}=1\right)$ の 2 通りの場合に限 られる. 式(1)左辺の $y_{j, t}^{i}$ は[0-1]変数であるため, 既存施 設が存在する状況下 $\left(y_{j, t-1}^{i}=1\right)$ で施設を更新する $\left(z_{j, t}^{i}=1\right)$ ためには, 既存の施設を廃止 $\left(v_{j, t}^{i}=1\right)$ しなけ ればならないことを示している．また， $t$ 期に施設が存 在しない状況 $\left(y_{j, t}^{i}=0\right)$ となるのは, c) $t-1$ 期に施設が存 在せず $\left(y_{j, t-1}^{i}=0\right)$, さらに $t$ 期に更新・廃止をしない 場合 $\left(z_{j, t}^{i}=v_{j, t}^{i}=0\right)$, d $) t-1$ 期に施設が存在し $\left(y_{j, t-1}^{i}=\right.$ 1), これを $t$ 期に廃止して更新は行わない場合 $\left(z_{j, t}^{i}=0, v_{j, t}^{i}=1\right)$ のいすれかであることを表している. 式(1)は， $t$ 期に施設を更新し同時期に廃止する $\left(z_{j, t}^{i}=v_{j, t}^{i}=1\right)$ ケースでも成立するが，これは更新費 用が無駄になるため最適解にはなりえない.

さらに, $t$ 期に規模 $i$ の施設 $j$ を廃止する場合は, $t-1$ 期 に規模 $i$ の施設 $j$ が存在していなければならないことを 表現するために

$$
v_{j, t}^{i} \leq y_{j, t-1}^{i} \quad \forall i \in I, \forall j \in J, \forall t \in T
$$

を制約条件式として考慮する。これにより廃止と更新の 組み合わせは，上記の a)-d)の 4つのケースに限定される. 規模 $i$ の施設 $j$ の供用年数 $q_{j, t}^{i}$ の変化を次のように表す.

$$
\begin{gathered}
q_{j, t}^{i} \geq q_{j, t-1}^{i}+y_{j, t}^{i}-U v_{j, t}^{i} \quad \forall i \in I, \forall j \in J, \forall t \in T \\
q_{j, t}^{i} \geq z_{j, t}^{i} \quad \forall i \in I, \forall j \in J, \forall t \in T
\end{gathered}
$$

ただし，Uは計算上用いる十分に大きな正の定数であ る.これらの制約条件式は上記の a)-d)の 4つのケースに ついて, a) $t-1$ 期に存在した施設を更新・廃止せず存続 した場合には $\left.q_{j, t}^{i} \geq q_{j, t-1}^{i}+1, \quad b\right) t$ 期に施設を廃止・施 設を更新する場合には $q_{j, t}^{i} \geq 1$, c) $t-1$ 期に施設が存在せ ず $t$ 期に更新・廃止をしない場合には $q_{j, t}^{i} \geq 0$, d) $t$ 期に
既存の施設を廃止する場合には $q_{j, t}^{i} \geq 0$ となるように工 夫されている. ここで維持管理費用は, 供用年数に関し て単調増加関数を仮定する. したがって, 費用を小さく 寸るためには，供用年数 $q_{j, t}^{i}$ は不等式の制約の中で最小 值をとることになるので，施設を存続すれば 1 年古くな り，施設を更新寸れば 1 年目から開始され，施設が存在 しなければ供用年数の值は 0 となる. 以上の式(1)から(4) が，本モデルの最も特徽的な工夫点であり，これらによ って施設の供用年数を内生的に扱うことが可能となって いる.

\section{(4) 混合整数計画問題としての定式化}

本研究では式(1)-(4)を含む制約条件の下で, 廃棄物の 輸送，処理費用および施設の維持管理費用，更新費用を 現在価值に換算し，計画期間中で合計した式(5)の目的 関数を最小化するような次の混合整数計画問題を考える.

$$
\begin{aligned}
\min _{x_{k j, t}^{i}, y_{j, t}^{i}, i_{j, t}^{i}, q_{j, t}^{i}, v_{j, t}^{i}} \sum_{t \in T} \beta^{(t-1)}\left\{\sum_{i \in I} \sum_{k \in K} \sum_{j \in J}\left(c_{k j}+w^{i}\right) x_{k j, t}^{i}\right. \\
\left.+\sum_{i \in I} \sum_{j \in J} r_{j}^{i} q_{j, t}^{i}+\sum_{i \in I} \sum_{j \in J} f_{j}^{i} z_{j, t}^{i}\right\}
\end{aligned}
$$

s.t.

(1), (2), (3), (4),

$$
\begin{array}{cr}
\sum_{i \in I} \sum_{j \in J} x_{k j, t}^{i}=G_{k, t} & \forall k \in K, \forall t \in T \\
\sum_{k \in K} x_{k j, t}^{i} \leq M_{j}^{i} y_{j, t}^{i} & \forall i \in I, \forall j \in J, \forall t \in T \\
\sum_{i \in I} z_{j, t}^{i} \leq \sum_{i \in I} v_{j, t}^{i} & \forall i \in I, \forall j \in J, \forall t \in T \\
\sum_{i \in I} z_{j, t}^{i} \leq 1 & \\
x_{k j, t}^{i} \geq 0 \quad \forall i \in I, \forall k \in K, \forall j \in J, \forall t \in T \\
x_{k j, t}^{i} \in \mathbb{R} \quad \forall i \in I, \forall k \in K, \forall j \in J, \forall t \in T \\
y_{j, t}^{i}, z_{j, t}^{i}, v_{j, t}^{i} \in\{0,1\} & \forall i \in I, \forall j \in J, \forall t \in T \\
q_{j, t}^{i} \in \mathbb{Z} & \forall i \in I, \forall j \in J, \forall t \in T \\
q_{j, t}^{i} \geq 0 & \forall i \in I, \forall j \in J, \forall t \in T \\
q_{j, 0}^{i}=Q_{j}^{i} & \forall j \in J \\
y_{j, 0}^{i}=y_{j}^{i} & \forall j \in J
\end{array}
$$

ただし， $\beta=1 /(1+\gamma)$ であり, $\gamma$ は割引率である. 式 (5)の目的関数は各期に生じる費用を割引いたうえで計 画期間中の全期間で足し合わせた総費用を表している. その第一項は廃棄物の輸送費用と処理費用を表し，単位 廃棄物量あたりの輸送費用 $c_{k j}$ と処理費用 $w^{i}$ を加えたも のに $k j$ 間の廃棄物輸送量 $x_{k j, t}^{i}$ を掛け合わせて表現する. 第二項は施設の維持管理費用を表し, 施設 $j$ の供用年数 を表す $q_{j, t}^{i}$ に比例して増大寸ると考え, 係数 $r_{j}^{i}$ を掛け合 わせることで表現する．第三項は施設の更新費用を表し， 
更新後の施設の規模に見合った費用を表す $f_{j}^{i}$ と，各期の 更新を表す $[0-1]$ 变数である $z_{j, t}^{i}$ との積で表現する. 維持 管理費用・更新費用は施設の規模iの違いで大きさが異 なると設定する.

式(6)は，各 $t$ 期において廃棄物発生地点 $k$ から輸送さ れる全ての廃棄物の合計が廃棄物の発生量 $G_{k, t}$ に等しい というフロー保存則を表している. 式(7)は，地点 $j$ の施 設に輸送される総廃棄物量が施設の処理可能量 $M_{j}^{i}$ を超 えないことを表す. 処理可能量 $M_{j}^{i}$ は施設の規模 $i$ によっ て異なるため, 地点 $j$ における規模 $i$ の施設の有無を表 す $[0-1]$ 変数 $y_{j, t}^{i}$ を $M_{j}^{i}$ に掛け合わせて表現する. これらの 式(5),(6)の制約は，容量制約付最適施設配置問題におけ る標淮的な制約条件である9，10).

式(8)は，施設を更新するには同じ期に施設を廃止す ることが必要であることを表現している．式(9)は， $t$ 期 に施設を更新する際に一つの規模を選ぶことを表してい る. 寸なわち $z_{j, t}^{i}$ は規模 $i$ につて多くても一つだけが 1 をとる. 式(10)〜(14)は，各操作変数の定義域を表してい る. 式(15), (16)は，外生的に与えられる施設配置と初期 の供用年数の初期条件であり, 初期における施設の規模 と供用年数に関する初期值は， $Y_{j}^{i}$ および $Q_{j}^{i}$ として外生 的に与えられる.

以上の定式化した問題を, IBM 社の CPLEX Optimizar を使用して最適化計算を行う。

\section{3. 仮想施設群に対する数値実験}

\section{(1) 地理的条件の設定}

ここでは仮想的な施設群に適用し，本モデルの特性を 考察寸る. 具体的には，地理的条件が異なる二つのケー スを設定し，この条件の違いが施設の更新・廃止計画の 特性に与える影響を明らかにする。

図-1のように，正6角形上に位置する6つの地点（図中 の丸印）から同量の廃棄物が毎期，発生し，それを既存 の3つのごみ処理施設（図中の四角印）で焼却処理する 状況を考える. 3つのごみ処理施設は正6角形の重心と2 つの発生地点の中点を結ぶ值線上に位置するように設定 し，ケースa)では施設が正6角形の外側に位置し，互い に離れている場合と，ケースb)では正6角形の重心の近 傍に位置し，相互の距離が小さい場合の $2 つ の$ 地理的配

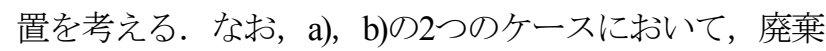
物処理施設から最近傍の $2 つ の$ 廃棄物発生地点までの距 離が等しくなるように設定する.

\section{(2) パラメータの設定}

\section{a) 計画期間}

廃棄物処理施設の寿命は，約 20-30 年であることを踏

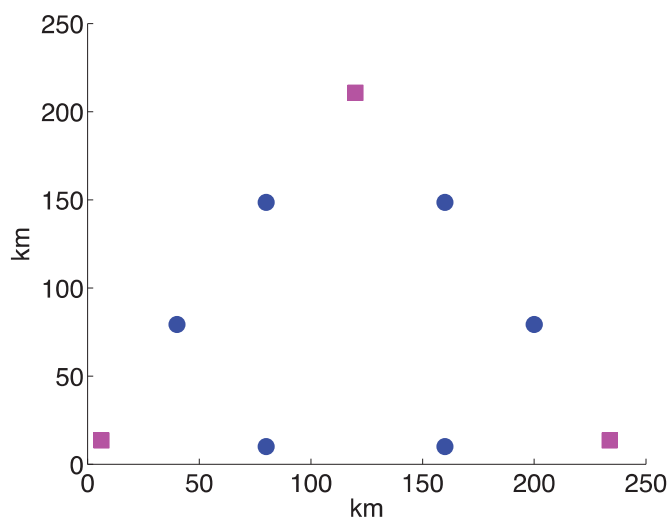

a)施設間の距離が遠い場合

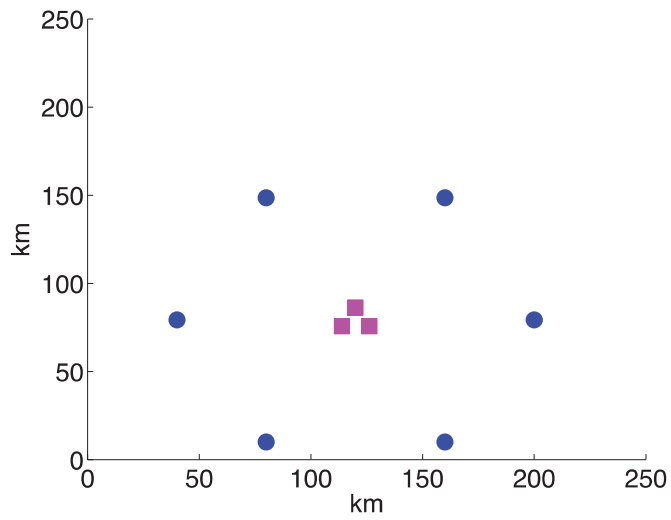

b）施設間の距離が近い場合

図-1 廃棄物発生地点(丸印) と処理施設位置(四角)の設定

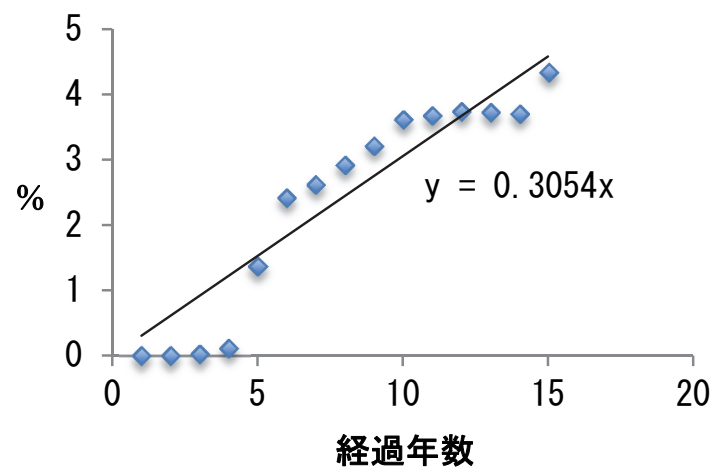

図-2 施設の経過年数に伴う維持管理費用の変化

まえて計画期間を 30 年とする $(t \in\{1,30\})$.

b) 施設の規模 $i$ と処理可能量 $M_{j}^{i}$

既存施設の規模をLargeとして $i=l$ と表す．更新時に既 存施設と同じ規模の施設に更新寸る場合を $i=l$, 既存施 設の半分の規模(Small)の施設に更新する場合には， $i=s$ と 表す. 更新前の既存施設の処理可能量は3つの施設とも 60,000 トンであり $, M_{j}^{l}=60000, M_{j}^{s}=0.5 \times M_{j}^{l}=30000$ と設定する.

$$
M_{j}^{i}=\left[M_{j}^{s}, M_{j}^{l}\right]=\left[0.5 \times M_{j}^{l}, M_{j}^{l}\right]
$$

c) 将来の廃棄物発生量 $G_{k, t}$

人口の減少によって各廃棄物発生地点の発生量が, 
年々減少する状況を設定する. 初期時点 $(t=1)$ における年 間の発生量は20,000トンであり，その後 1 年ごとに 200 卜 ンずつ発生量が減少すると仮定し, 次のように設定する.

$$
G_{k, t}=20000-200(t-1)
$$

\section{d) 単位輸送費 $c_{k j}$ と処理費用 $w$}

既往研究 ${ }^{11)}$ 参考に，1,000 円 $/ \mathrm{km}$ ・トンで輸送費用が 生じるとする. 各施設の処理費用は, 平成 22 年度にお ける宮城県全体の直接焼却量 ${ }^{12)}$ をゴミ処理費用で割った 值を参考に施設規模に関わらず $(i=l, s)$,

$$
w^{l}=w^{s}=w=10,000(\text { 円/トン })
$$

\section{と設定した。}

\section{e) 更新費用 $f_{j}^{i}$}

更新費用は施設の建設費用と等しいと考え，環境省 による廃棄物処理施設設置費用調査結果 ${ }^{13)}$ より設定する. 建設費用は各施設の一日あたりの処理可能量に比例する と考え，年間稼働日数を 280 日として一日当たりの処理 可能量 $(1 / 280) M_{j}^{i}$ に係数 $\alpha=5.0\left(10^{7}\right.$ 円/トン $)$ かけて 更新費用を表現する.

$$
f_{j}^{i}=\left[f_{j}^{s}, f_{j}^{l}\right]=\left[0.5 \times \frac{1}{280} M_{j}^{l}, \alpha \times \frac{1}{280} M_{j}^{l}\right]
$$

\section{f）維持管理費用 $r_{j}^{i}$}

ごみ焼却施設長寿命化計画作成の手引き(ゴミ焼却施 設編 $)^{14)}$ では, ごみ焼却施設が経過年数に対して建設費用 に対する維持管理費用の割合の経年的推移の実績データ が掲載されている. 本研究においては, 図-2 に示すよ うに，建設費用に対する維持管理費用の経年変化を線形 近似し，下式に基づいて維持管理費用を算出した.

$$
r_{j}^{i}=\frac{0.3054}{100} \times f_{j}^{i}
$$

（3）地理的配置による最適更新パターンの違い

\section{a) 施設間の距離が遠い場合}

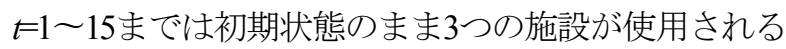
(図-3) . 図中の四角は，既存施設の規模 $(i=l)$ が配置さ れていることを表している. 規模に更新される(図中の三角)が, 更新後の施設の処理 能力が不足するため一部分が既存の規模の施設に遠距離 輸送される（図-4）。その後, $t=26$ になると全体の発生 量が十分少なくなるので，残りの 1 施設が $i=s の$ 規模の施 設に更新され，再び3つの施設が2つずつの地域からの廃 棄物を処理することとなる（図-5）。

このときの廃衰物の処理費用, 輸送費用, 施設の維持 管理費用，更新費用の累積值の推移を図-6に示寸。この 図から，総費用に占める輸送費用の割合が大きいことが 確認できる。これは, 廃棄物処理事業経費に占める収

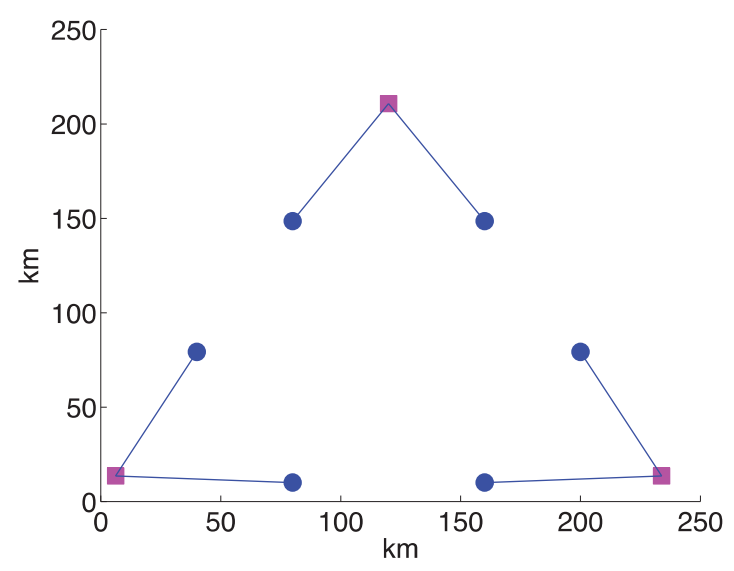

図-3 $t=1 \sim 15$ の処理形態

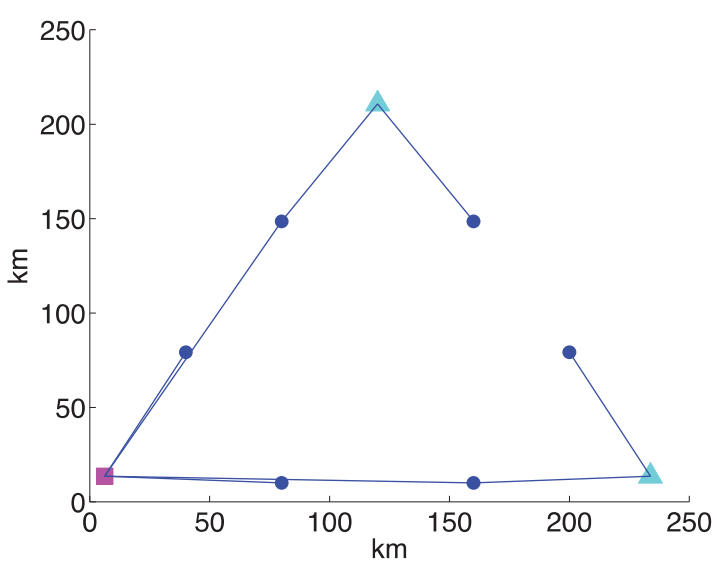

図-4 $t=16 \sim 25$ の処理形態

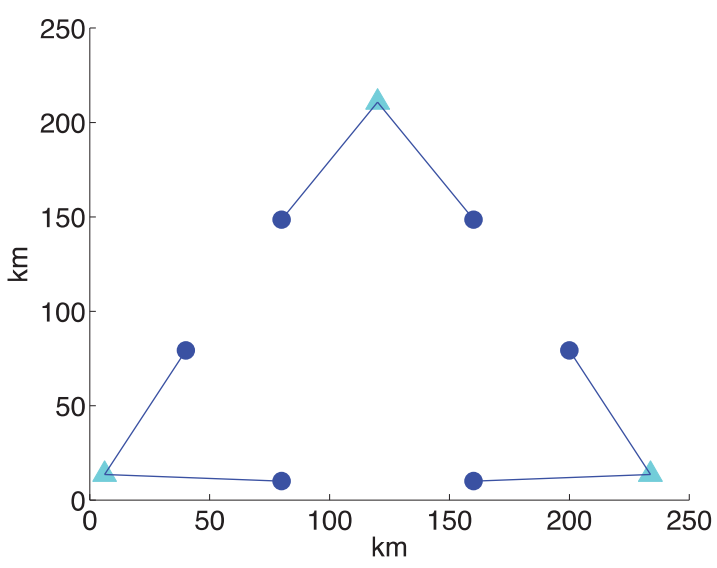

図-5 $t=26 \sim 30$ の処理形態

集・運搬経費の占める割合が大きいという実情15をを良く 表現した結果であるといえる.また施設の更新が行われ たた 16 期目と 26 期目において施設の更新費用が発生し, 累積費用に不連続な変化が起きている. 以下では, 維持 管理費用, 輸送費用の経年変化について詳しく述べる. 


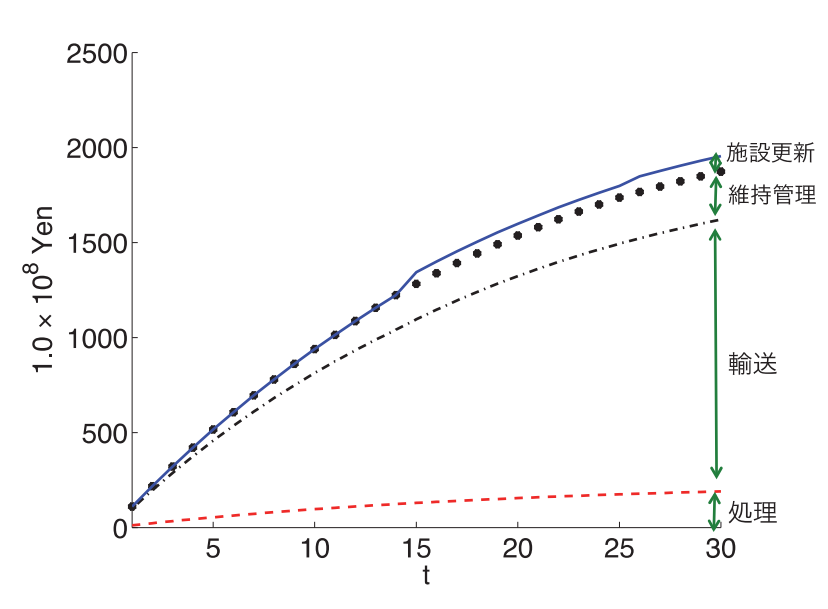

図-6 累積費用（現在価値）の推移

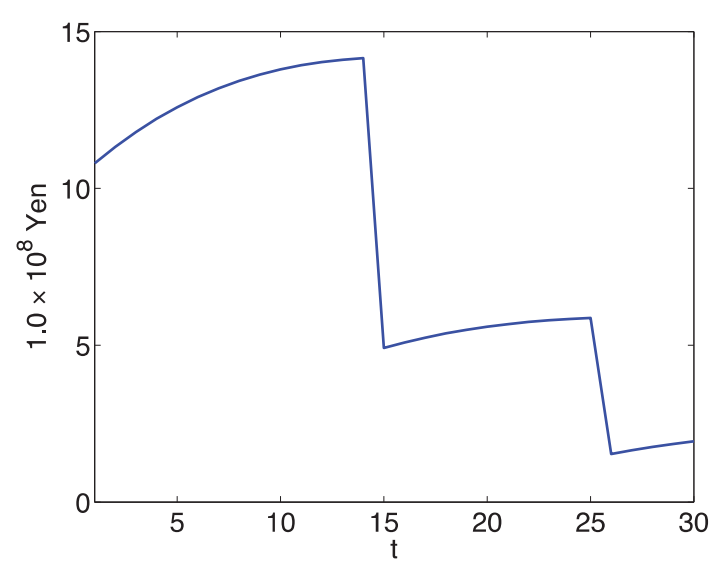

図-7 維持管理費用（現在価值）の経年変化

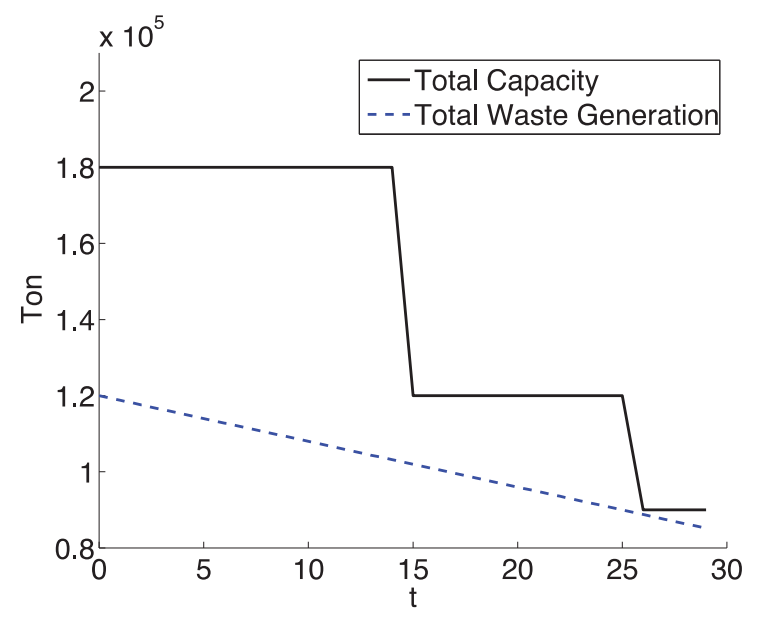

図-8 総廃棄物量と施設の総利用可能量の経年変化

図-7は時間の経過と割引後の施設の維持管理費用との 関係を表している.この図から経年的に維持管理費用が 上昇していき，施設規模を小さいものに置き換える $(t=16$, 26)ごとに不連続に減少していることがわかる.この図 から，縮小更新は，i) 供用年数に比例して増加した維持 管理費用を小さく抑える，ii) 施設の規模に比例する維持 管理費用を小さく抑える，という2つのルートで維持管 理費用を減少させていることがわかる，図-8は，総廃棄

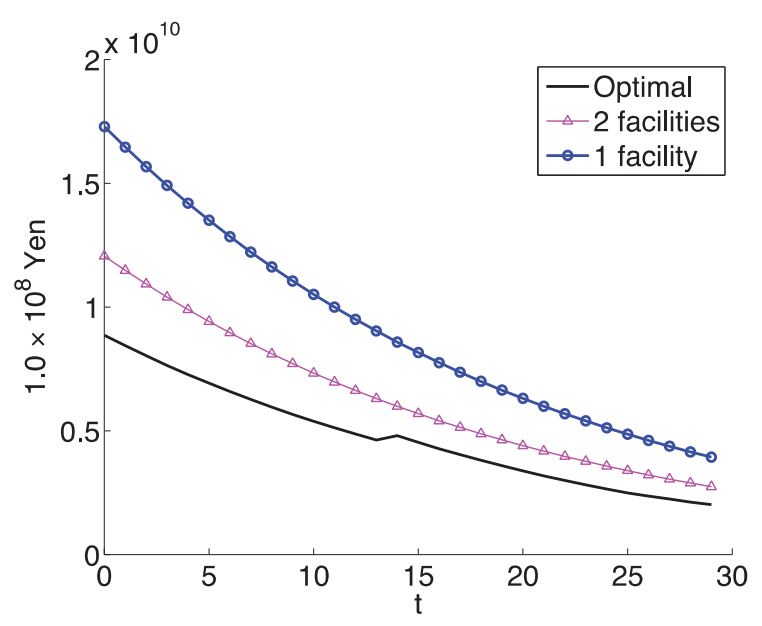

図-9 輸送費用（現在価値）の経年変化

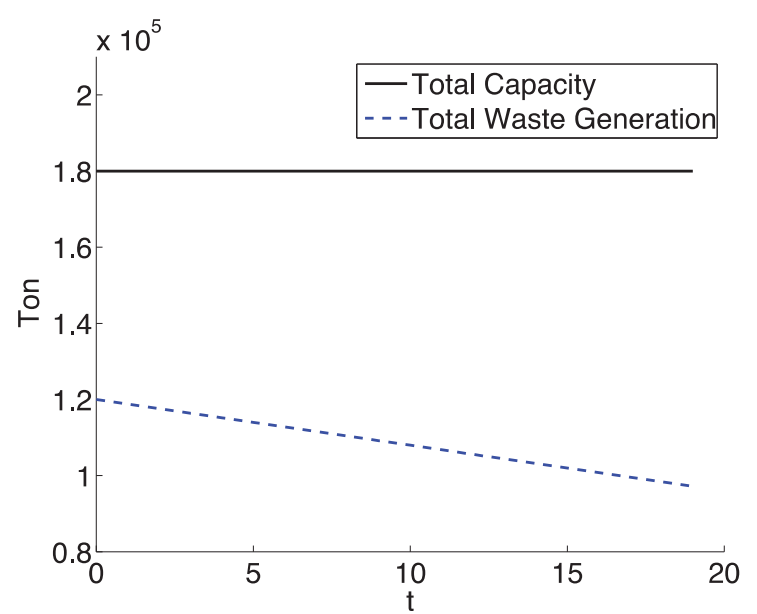

図-10 総廃衰物量と施設の総利用可能量の経年変化 $(T=20)$

物量（全ての地域の廃棄物発生量の合計）と施設の総処 理可能量（全ての利用可能な施設の処理可能量の合計） の経年的な变化であり, 施設の縮小更新は, 経年的に減 少する総廃棄物量に応じて実施されていることがわかる. すなわち, $t=1$ における総廃棄物量は 120,000 トンであり, 仮に 2 つの施設を縮小更新したとしても，3つの施設の 容量の合計を上回らない（全ての廃棄物を処理すること ができる）が，輸送費用の増加を抑えるために $t=16$ に なるまで施設は更新されない，その後，t=26の時点にお いて総廃棄物量は 90,000 トンになり，全 3施設を縮小し た施設に更新した場合の処理可能量に一致している.つ まり処理能力の制約がなくなった瞬間に縮小更新が行わ れていることがわかる. 図-9 の実線は最適な更新・廃 止計画を実施した場合の輸送費用(現在価值)の経年変化 である．これから，経年的に廃棄物の発生量が減少して いくに伴って輸送費用が減少していくことが確認できる。 また， $t=16$ の時点において縮小更新した施設の処理能 力が不足したため, 別の施設に遠距離輸送する必要が生 じ，輸送費用が増加していることがわかる．図-9 中に は，最適な更新計画を実施した場合(3 施設とも維持する, 図中の実線)に加えて, 施設を 2 箇所(図中の三角印)また 
は 1 箇所(図中の丸印)だけ外生的に与えた場合の輸送費 用(現在価值)の経年変化を示している. この図から，施 設数が少なくなるほど，より遠い距離を輸送する必要が 生じるため，輸送費用が大きくなっていることがわかる。 これは，b)施設間の距離が近い場合(次項, 図-15)に比べ て施設の廃止による輸送費用の増加分が大きいことを意 味している．したがって，施設間の距離が遠い場合には， 施設の廃止による維持管理費用の減少効果よりも，輸送 費用の増加分が大きいため施設は廃止されにくく，縮小 更新しながら，3 つの施設を維持していくことが最適な 更新・廃止計画となる。

施設の最適な更新計画は計画期間の影響を受ける。す なわち，施設の縮小更新は，更新後の毎期の維持管理費 用を減少させるため, 更新時から計画最終期までの期間 が短ければ維持管理費用の減少効果は小さくなる。例え ば，計画期間を $T=30$ 期間から 20 期間に変更して同じ問題 を解いた図-10の場合には, 総廃棄物量と施設の処理可 能量との関係で縮小更新が可能になったとしても，その 後の期間が短く, 輸送費用の増加分に比べて維持管理費 用の減少効果が小さいため，施設の縮小更新は行われず， 既存の規模のまま, 更新も廃止もせずに施設を維持して いくことが最適な更新・廃止計画となる.

\section{b) 施設間の距離が近い場合}

計画期間の初期時点 $(t 1)$ において，施設を 1 箇所だけ 廃止し, その後は初期の規模のまま2つの施設を使用し 続けるという結果が得られた（図-11）。図-12は, 総廃 棄物量と施設の総処理可能量の経年的な変化であり, 計 画開始時に, 初期時点 $(t=1)$ の総廃棄物を処理するのに十 分な処理可能量が残るように，1箇所だけ施設を廃止し ていることが確認できる. 90,000 トンとなり，残存する施設のうちの1つを縮小更新 しても処理能力が確保できる状況となるが，それ以降， 計画期間の最終期まで5期しかなく，更新費用を賄うだ けの維持管理費用の減少効果が得られない。そのため, 計画初期時点での施設の廃止のみを行うことが最適な更 新・廃止計画となる.

各費用の累積值の推移は図-13の通りであり, 全ての 施設は更新されないため, 更新費用が発生しない. 3つ の費用区分の中では, 図-6と同様に，総費用に占める輸 送費用の割合が大きく，実情15を良く表した結果である といえる．施設の構成に変化がないため維持管理費用は 全期間にわたり連続的に変化するが，全処理量の減少に 伴って $=16$ 以降は減少に転じている（図-14）。また,

図-15には最適な更新・廃止計画 (初期時点から2籄所の 施設を利用する) 場合の輸送費用の経年変化を実線で示 している.これと，施設を1箇所(図中の丸印)，3箇所(図 中の四角印利用した場合の輸送費用の差異を見ると前

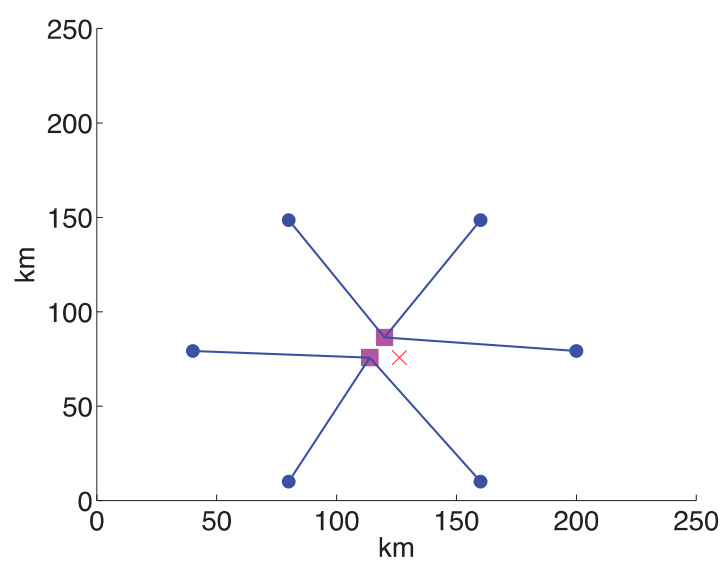

図-11 $t=1 \sim 30$ の処理形態

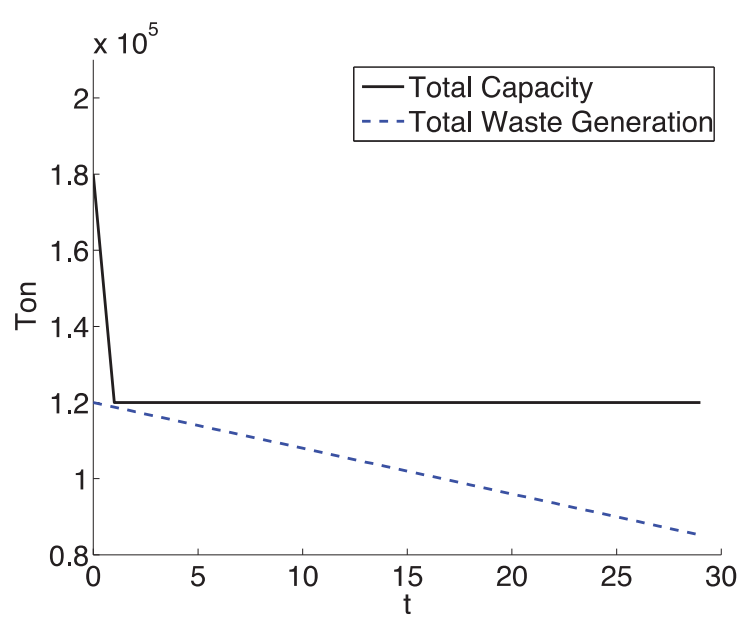

図-12 総廃棄物量と施設の総利用可能量の経年変化

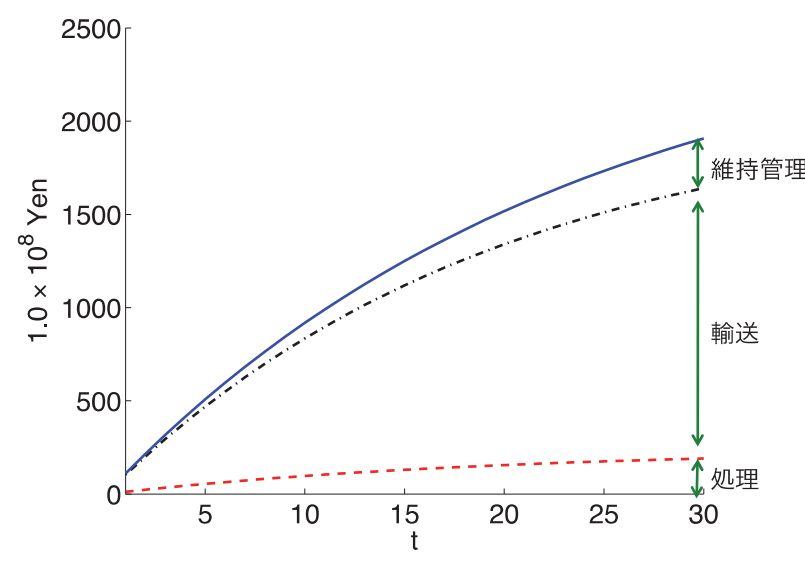

図-13 累積費用（現在価值）の推移

項a) の場合に比べて小さく, 施設の廃止による輸送費用 の増加分が小さかったことがわかる.このため, 計画の 初期時点ですぐに $1 つ の$ 施設を廃止することが，最適な 更新・廃止計画となった.

\section{c) 施設の地理的配置がもたらす影響}

以上のa), b)の $2 つ の$ 地理的条件の比較から，施設の費 用構造が全く同じであっても, 施設の更新・廃止の戦略 


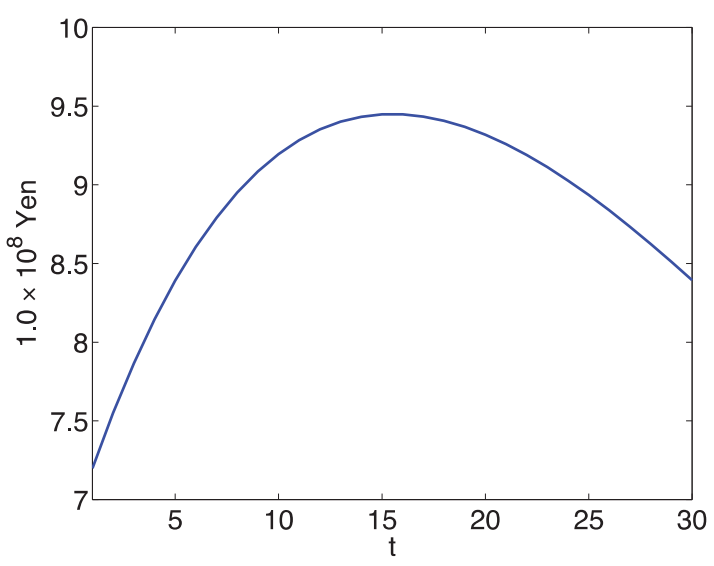

図-14 維持管理費用（現在価值）の経年変化

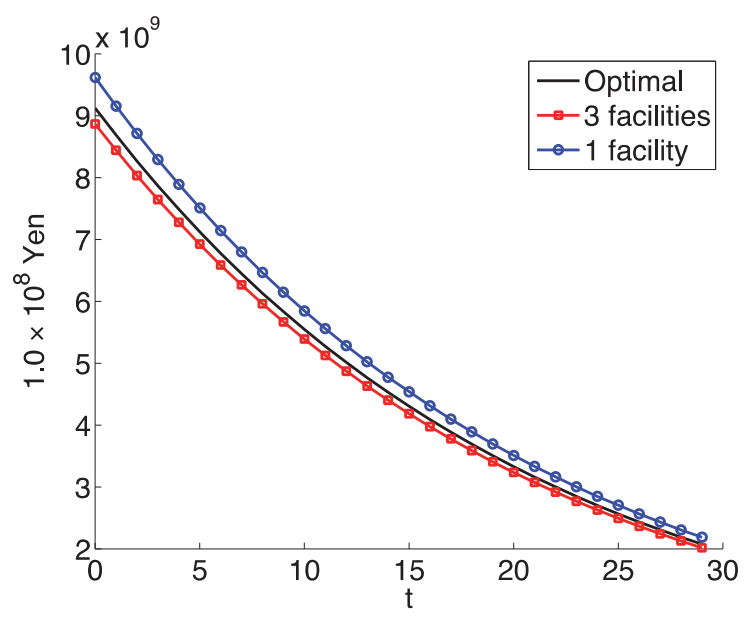

図-15 輸送費用（現在価值）の経年変化

は異なることが確認できた。すなおち施設間の距離が遠 い a)の設定では，既存の施設を廃止することによる輸 送費用の増加分が大きいため, 施設は廃止されにくい. 逆に施設間の距離が近いb)の設定では，縮小更新や廃 止をより迅速に行って全体の費用を効果的に節約するこ とが可能である.

言い換えれば，これらの2つのケースの違いは施設間 の代替性の強さであると解釈できる，すなおち，施設間 の距離が近ければ，他の施設で代替しやすいため，比較 的早い段階で施設の更新や廃止が可能になる. しかし, たとえ地理的にはb)の状況でも, 異なる広域連合に属し ているため近隣の施設が廃棄物を受け入れできないよう な制度的制約がある場合，施設間の代替性はなくなり， 縮小更新や廃止の決定が遅くなると考えられる．ここで， 人口減少による廃革物発生量の減少が予想される中での 施設の地理的条件がもたらす影響を，さらに詳しく見る. 仮に地理的条件を考慮せず，施設の維持管理費用を節約 するため, 現在の廃棄物を処理するのに必要最低限の施 設だけを残す場合を考える。すなおち，計画期間の初期 時点においては，合計 120,000 トン（=6地点 $\times 20,000$ トン） の廃棄物が発生しているため，既存の施設（容量 60,000

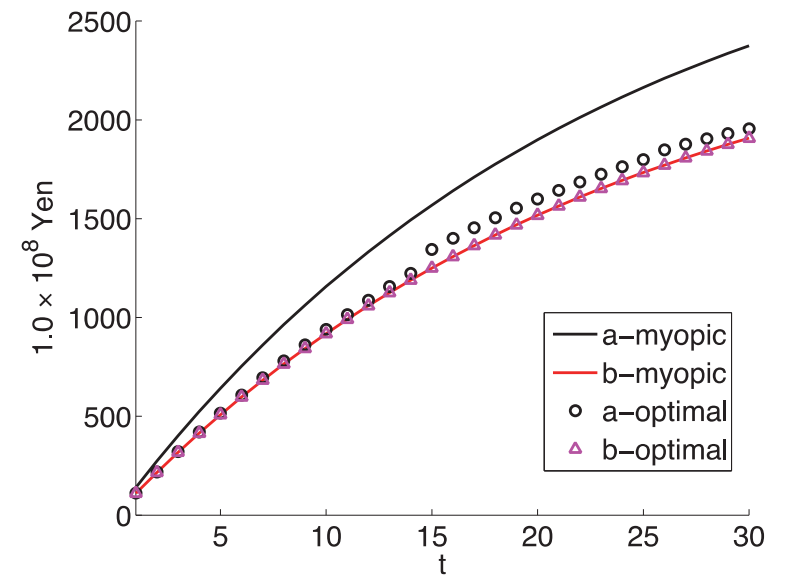

図-16 近視眼的な更新・廃止計画の総費用の推移

トン）を1力所だけ廃止し，残りの2力所で処理する計画 を考え，近視眼的計画(myopic)と呼ぶこととする．地理 的条件a),b)それぞれのケースにおいて，本節で分析して きた最適な更新・廃止計画(a-optimal, b-optimal)と，近視眼 的計画(a-myopic, b-myopic)による更新・廃止計画のもとで 輸送量に関して最適化した結果を比較する.

図-16は4つのケースにおける総費用の経年的推移を示 している．施設間の代替性が強いb)のケースでは，近視 眼的計画と最適計画の更新・廃止計画は等しいため, 総 費用は等しい結果となっている. しかし，施設間の代替 性がないa)のケースでは，最適な計画に比べて，近視眼 的計画では毎期, 総費用が約1.2倍に増加することにな る. これは，一つの施設の廃止によって遠距離輸送が必 要になり，輸送費用が増加したためである.

以上から，既存の施設間の距離が遠く，代替性がない 場合には，施設の地理的条件を考慮した更新・廃止計画 が望まれるといえる，また，本モデルは，施設の維持管 理費用だけでなく，地理的条件もふまえた上で更新・廃 止計画を定量的に評価する枠組夕を提供している.

\section{4. 設定条件の変更による影響分析}

\section{（1）廃棄物発生量による最適更新パターンの違い}

まず，第 3 章のケースと比較して，廃杗物発生量の設 定のみが異なり，廃棄物発生量が経年的に変化せず，各 発生点で毎期 20,000 トンずつ発生する状況を設定する. 第 3 章の分析と同様に, a)施設間の距離が遠い場合とb) 施設間の距離が近い場合の 2 つ地理的条件について分 析を行った.

\section{a) 施設間の距離が遠い場合}

計画期間内に施設の更新・廃止は起こらず，期末まで 既存施設を維持し続けるという結果となった。これは, 需要量が一定の状況下では，縮小更新や廃止をすると輸 
送費用が大幅に増加してしまうため, 更新や廃止の戦略 がとりにくいことの結果であると考えられる.

\section{b) 施設間の距離が近い場合}

$t=1$ の時点で施設を 1 廃止し, その後は初期の規模 のまま $2 つ の$ 施設を使用し続けるという結果となり，第 3 章のケースと全く同じ結果が得られた.

以上のことより, 廃棄物の発生量が減少するという条 件が，既存施設の更新・廃止計画に大きな影響を持って いることが確認できた.

\section{（2）維持管理費用による最適更新パターンの違い}

次に第 3 章のケースと比較して, 維持管理費用の設定 のみが異なり，維持管理費用が施設の供用年数 $q_{j, t}^{i}$ に対 して変化せず一定である場合を考える. このときの固定 維持管理費用は施設の規模 $i$ によって異なるが，両者と も第 3 章の分析で供用年数が 15 年経過した施設にかか るのと同等の費用が毎期生じると設定した.

この変更により, 施設の供用年数の変化は目的関数に 影響を与えなくなるため, 第 3 章の結果との比較を通じ て本モデルの特徴である供用年数の内生化の効果を知る ことができる.ここでも，第 3 章の分析と同様に，a)施 設間の距離が遠い場合と，b)施設間の距離が近い場合の 2つの地理的配置について分析を行った.

\section{a) 施設間の距離が遠い場合}

計画期間内に施設の更新・廃止は起こらず，計画期間 が終わるまで既存施設を維持し続けるという結果になっ た(図-17). 本モデルでは，施設の更新により，i) 施設の 供用年数に比例する維持管理費用を小さく抑える, ii)施 設を縮小更新して，施設規模に比例する維持管理費用を 小さく抑える，という2つのルートで維持管理費用が減 少することを指摘した. ここで維持管理費用が供用年数 に関して一定であると仮定したことにより i)の効果が失 われ，施設更新による費用の減少効果は ii)のみとなって, 第 3 章(3)節の場合よりも小さくなる. この結果, 更新費 用と輸送費用の増加分に見合うだけの効果が得られなく なり, 第 3 章(3)節の $t=16$ 期の時点で行われた縮小更新 (図-8, 9 参照)は行われない(図-18). さらに, 輸送費用の 大きな増加をもたらす施設の廃止も行われない結果とな った．以上から，供用年数に関わらず維持管理費用が一 定であるとしてしまうことは, 更新による維持管理費用 の減少効果を過小に評価することにつながることが確認 できた.

\section{b) 施設間の距離が近い場合}

計画期間の初期時点 $(t=1)$ において, 施設を 1 つ廃止し, その後は初期の規模のまま 2 つ施設を使用し続けると いう結果となり, 第 3 章(3) b)の更新・廃止パターンと 全く同じ結果が得られた．上述したように，維持管理費 用が供用年数によらず一定という仮定をおいた場合には,

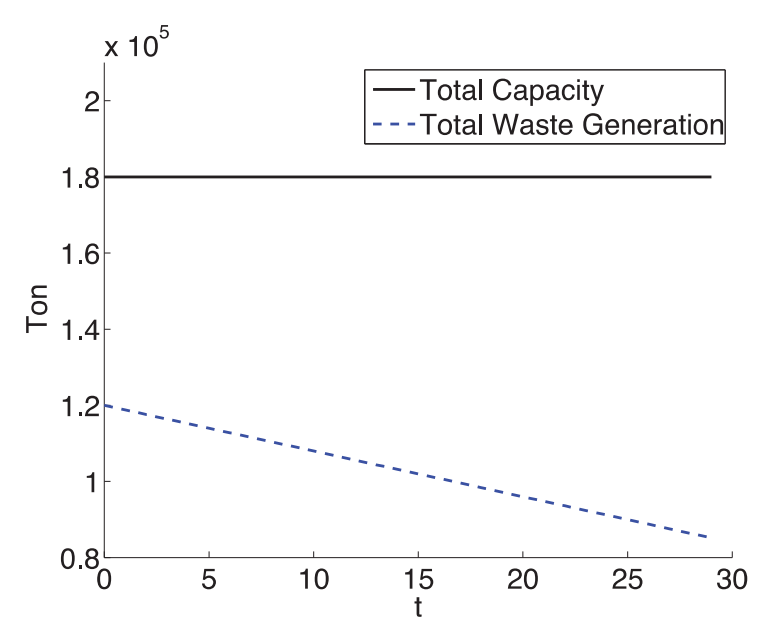

図-17 総廃棄物量と施設の総利用可能量の経年変化

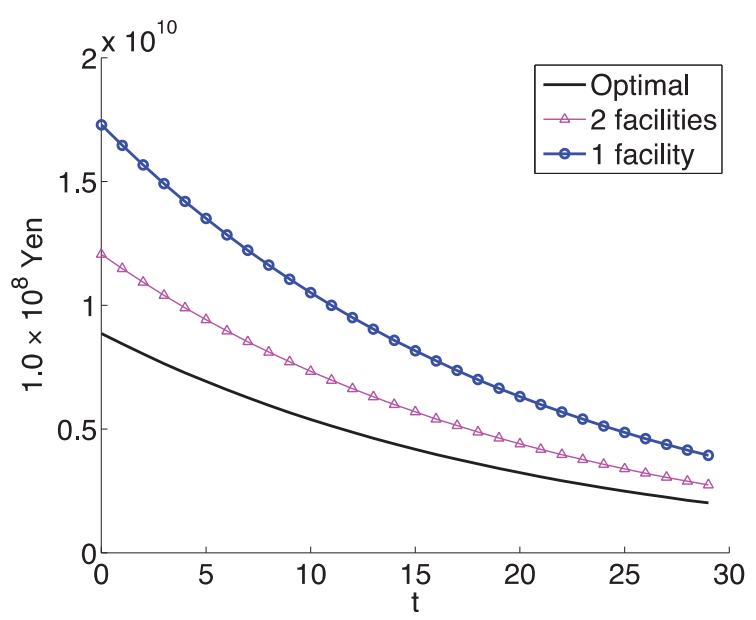

図-18 輸送費用（現在価值）の経年変化

ii)施設の縮小更新による維持管理費用の減少効果のみが

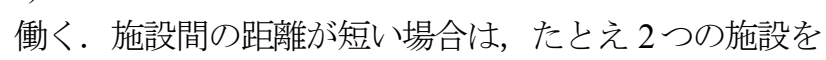
廃止したとしても，残りの 1 つの施設がすぐ近くにある ため, 輸送費用の増加分は小さい(図-15 参照). したが って廃棄物の総排出量に応じた縮小更新が，計画開始初 期時点すぐに行われる結果となった.

以上のことから施設の供用年数の増加に伴う維持管理 費用の経年的な増加は, 既存施設の更新・廃止計画に影 響を及ぼしていることが確認できた，これにより，本モ デルで行ったような施設の供用年数の内生化は, 施設を 長期的に効率良く運用していく上で，重要な要素である ことが確認できた.

\section{5. おわりに}

更新や廃止の戦略は，廃棄物の発生量が減少する中で, 施設の維持管理費用が毎期増加するという場合に特に有 効な戦略であることがわかった．また具体的な更新・廃 止計画は，施設間の代替性の強さに大きく依存しており， 地理的な条件の影響を大きく受けることが確認された. 
現代の日本は, 人口減少による需要の減少とインフラ の老朽化に伴う維持管理費用の増加という問題を同時に 抱えているため，提案したモデルを用いた分析が有用な 知見をもたらすような状況にあると考えられる.

今後の課題として, 混合整数計画法の実用的な求解が 可能な問題のサイズを明らかにし，市町村間の広域的な 連合の形成に伴う更新・廃止計画の実用的な問題への適 用を図ることが求められる.

謝辞 : 本研究は日本学術振興会・科学研究費補助金（課 題番号 : 24760405) の助成を受けたものである.

\section{参考文献}

1）総務省，公共施設等総合管理計画の策定にあたって の指針（案）の概要について， 2014. http://www. soumu.go.jp/main_content/000270732.pdf

2) さいたま市, 第 3 次さいたま市一般廃裹物処理基本 計 画, 2012. (http://www.city.saitama.jp/001/006/006/ p016952.html)

3) 栗野盛光, 小林潔司, 渡辺晴彦: 不確実性下におけ る最適補修投資ルール, 土木学会論文集, No. 667/IV-50, pp.1-14, 2001.

4) 小林潔司，江口利幸，大井明，青木一也，貝戸清之， 松村泰典: 舗装構造の最適補修更新モデル, 土木学 会論文集 E1 (舗装工学)，Vol. 68, No. 2, pp. 54-68, 2012.

5) 小澤一雅：特集 設備形成・運用へのアセットマネジ メント技術の浸透-1 社会資本への導入, IEEJ Journal, Vol. 130, No. 2, pp. 72-75, 2010.
6) 江橋正俊, 中村祐司, 小澤一雅 : 資産運用に着目し た社会資本のアセットマネジメント，建設マネジメ ント研究論文集, Vol. 12, pp. 333-342, 2005.

7) 織田澤利守, 山本浩司, 青木一也, 小林潔司 : 道路 付帯施設の最適補修同期化政策，土木学会論文集 F, Vol. 64, No. 2, pp. 200-217, 2008.

8）堀倫裕, 小濱健吾, 貝戸清之, 小林潔司: 下水処理 施設の最適点検・補修モデル, 土木計画学研究・論 文集, Vol. 25, No.1, pp. 213-224, 2008.

9) Alizera, B., Arabani, R. and Zanjirani, F.: Facility location dynamics: An overview of classifications and applications, Computers \& Industrial Engineering, Vol. 62, pp. 408-420, 2012.

10) Wesolowsky, G. O. and Truscott, W. G.: The multi-period location-allocation problem with relocation of facilities, Management Science, Vol. 22, No. 1, pp. 57-65, 1975.

11）加用千裕, 石垣智基, 山田正人, 大迫政浩, 立尾浩 一: 東日本大震災で発生した災害廃棄物の広域処理 に関する一考察(第一報), 生活と環境, Vol. 57, pp. 3642, 2012.

12）環境省, 一般廃棄物処理実態調査結果, http://www. env.go.jp/recycle/waste_tech/ippan/

13) 環境省, 廃棄物処理施設設置費用調查結果, http:// www.env.go.jp/recycle/waste_tech/setti/

14）環境省大臣官房：廃棄物・リサイクル対策部廃棄物 対策課, 廃棄物処理施設長寿命化計画作成の手引き (ごみ焼却施設編)， 2010.

15）環境省大臣官房廃棄物・リサイクル対策部廃棄物対 策課, 日本の廃棄物処理（平成 23 年度版）， 2013 .

(2014. 2. 28 受付)

\section{MULTI-PERIOD OPTIMAL FACILITY LOCATION MODEL FOR RENOVATION AND ABOLITION PLANNING}

\section{Kazuaki OKUBO, Makoto OKUMURA and Tatsuki AGATSUMA}

In the demand decreasing trend for regional public facilities, efficient renovation plan must be discussed in order to avoid the possible increase of running and maintenance cost of the facilities. When there are two or more facilities of same functions in a region, abolition of facilities would become a promising option, if the present users can be reallocated to the neighbor facility. This paper proposes a multiperiod optimal facility location model as an integer programming model containing the endogenous variable of each facility's elapsed years. The model is applied to a renovation problem of 3 virtual waste treatment facilities serving to the waste generated from 6 municipalities, and the basic behavior of the model is clarified. 